\title{
Daya Hambat Minyak Serai Wangi (Andropogon nordus L.) terhadap Pertumbuhan Koloni Patogen Terbawa Benih secara In Vitro dan Pengaruhnya Terhadap Viabilitas dan Vigor Benih Terung (Solanum melongena L.) Effectiveness of In Vitro Inhibitory Effects of citronella oil (Andropogon nordus L.) on Controlling the growth of seed borne pathogens Colonies and the effect for viability and vigor of eegplant seed (Solanum melongena $\mathrm{L}$ ).
}

\author{
Aldina Cahaya ${ }^{1}$, Hasanuddin ${ }^{1}$ dan Syamsuddin ${ }^{1 *}$ \\ ${ }^{1}$ Program Studi Agroteknologi, Fakultas Pertanian, Universitas Syiah Kuala
}

\begin{abstract}
Abstrak. Penelitan tentang efektifitas minyak serai wangi dalam menghambat pertumbuhan koloni patogen terbawa benih secara in vitro dan pengaruhnya terhadap viabilitas dan vigor benih terung dilaksanakan di Laboratorium Ilmu dan Teknologi Benih Program Studi Agroteknologi Fakultas Pertanian Universitas Syiah Kuala yang berlangsung pada bulan Juni sampai dengan Agustus 2017. Penelitian ini bertujuan untuk mengetahui pengaruh jenis patogen dan konsentrasi minyak serai wangi serta interaksi antara jenis patogen dengan konsentrasi minyak serai wangi terhadap daya hambat pertumbuhan koloni patogen terbawa benih secara in vitro. Penelitian ini juga bertujuan untuk mengetahui konsentrasi minyak serai wangi yang efektif terhadap viabilitas dan vigor benih terung secara in vivo. Percobaan I menggunakan Rancangan Acak Lengkap (RAL) pola faktorial terdiri atas dua faktor, faktor pertama yang diteliti terdiri dari 6 taraf konsentrasi minyak serai wangi, faktor kedua adalah 2 taraf jenis isolat patogen dengan 3 ulangan sehingga diperoleh 36 satuan percobaan. Percobaan II menggunakan Rancangan Acak Lengkap (RAL) pola non faktorial yang terdiri dari 4 perlakuan dengan 5 ulangan sehingga diperoleh 20satuan unit percobaan. Hasil percobaan I menunjukkan bahwa Daya hambat pertumbuhan Rhizoctonia solani secara sempurna (100\%) diperoleh dengan pemberian minyak serai wangi pada konsentrasi $0,08 \%$. Sementara daya hambat $100 \%$ pada patogen Sclerotium rolfsii, diperoleh dengan pemberian minyak serai wangi pada konsentrasi $0,10 \%$. Hasil percobaan II menunjukkan bahwa perlakuan benih dengan minyak serai wangi tidak memberikan pengaruh negatif terhadap viabilitas dan vigor benih apabila konsentrasi yang digunakan dibawah $0,02 \%$.
\end{abstract}

Kata kunci: Serai Wangi, Patogen, Rhyzoctonia solani dan Sclerotium rolfsii

\begin{abstract}
The research of citronella oil effectivity on controlling the growth of seed borne pathogens under in vitro conditions and the effect for viability and vigor of eggplant seed.has been carried out in the laboratorium of seed, Departement of Agroteknologi, Agriculure Faculty, Syiah Kuala University was started from June until August 2017. The purpose of this study was to find out about the effect of pathoghen with citronella oil concentration and interact between pathogen with citronella oil concentration on controlling the growth of seed borne pathogens under in vitro conditions. The second purpose of this research was to find out about effectiveness of citronella oil to viability and vigor of eggplant seed under in vivo conditions. The first research used double randomize design method concisting with two standards,the first was using 6 concentrations of citronella oil, seconf was two kinds of pathogens and repeated 3 times to obtain 36 units of experiment. The second research used single randomized design method (CRD) consisting of 4 treatments and repeated 5 times to obtain 20 units of experiment. The results of the first research showed that the solubility of Rhyzoctonia solani growth (100\%) was obtained by administering citronella oil at a concentration of $0.08 \%$. While $100 \%$ inhibitory in Sclerotium rolfsii pathogens, obtained by administration of citronella oil at a concentration of $0.10 \%$. The results of experiment II showed that the seed treatment with citronella oil did not negatively affect the viability and vigor of the seeds when the concentration used was $0.02 \%$
\end{abstract}

Keywords : Citronella, Pathogens, Rhyzoctonia solani and Sclerotium rolfsii 


\section{PENDAHULUAN}

Terung (Solanum melongena L.) merupakan salah satu jenis tanaman penting hortikultura dari famili Solanaceae. Terung sangat popular dan disukai oleh masyarakat untuk dijadikan sebagai bahan sayuran dan lalapan. Menurut Badan Pusat Statistik dan Direktorat Jenderal Hortikultura (2016), produktivitas tanaman terung di Indonesia dari tahun 2011-2015 cenderung terus meningkat, yaitu sebesar 9,95 ton ha ${ }^{-1}, 10,26$ ton ha ${ }^{-1}, 10,76$ ton ha ${ }^{-1}, 10,95$ ton $\mathrm{ha}^{-1}$ dan 11,20 ton $\mathrm{ha}^{-1}$. Meskipun produktivitas terung nasional cenderung meningkat tiap tahunnya, produksi terung di Indonesia masih rendah dan hanya menyumbang $1 \%$ dari kebutuhan dunia (Simatupang, 2010).

Penggunaan benih bermutu rendah dan adanya gangguan penyakit tanaman merupakan salah satu faktor yang menyebabkan produksi terung masih rendah. Hingga saat ini masih memerlukan pengkajian secara lebih mendalam dan berkelanjutan untuk mendapatkan solusi pemecahan yang lebih baik dan tidak berdampak negatif terhadap lingkungan. Gangguan penyakit menimbulkan pengaruh yang jauh lebih luas karena sistem penyebarannya yang lebih cepat apalagi jika patogen itu terbawa benih (seed-borne) karena benih merupakan sumber penyebaran patogen.

Patogen terbawa benih mempunyai arti penting dari budidaya tanaman karena dapat mengurangi hasil produksi tanaman, menurunkan daya kecambah dan vigor benih, menyebabkan penyakit tanaman di lapangan, perubahan bentuk dan warna benih, perubahan biokimia benih, dan perubahan sifat fisik benih. Patogen terbawa benih dapat menyebabkan benih busuk, nekrosis pada benih, penurunan daya perkecambahan, serta kerusakan bibit yang mengakibatkan pengembangan penyakit pada tahap akhir dari pertumbuhan tanaman oleh infeksi sistemik atau local (Naqvi et al., 2013). Beberapa patogen penting yang terbawa benih terung antara lain Phytophthora sp, Fusarium sp, Rhizoctonia solani, Phytium dan Sclerotium rolfsii (Mamik, 2016). Keberadaan patogen yang terbawa oleh benih baik di permukaan maupun di dalam benih dapat terjadi epidemik penyakit karena transmisi patogen dari benih ke tanaman (Maude, 1996; Brandl 2001)

Dalam meningkatkan mutu benih, hal yang sangat penting untuk dilakukan adalah persiapan dan perlakuan benih sebelum tanam. Salah satu perlakuan benih (seed treatment) dengan fungisida nabati untuk mengendalikan penyebab kerusakan pada benih terutama yang disebabkan oleh cendawan. Fungisida nabati adalah zat yang berasal atau terdapat pada tanaman atau tumbuhan yang dapat mematikan atau menghambat pertumbuhan jamur. Kelebihan penggunaan fungisida nabati yaitu relatif lebih murah, ramah lingkungan serta banyak mengandung senyawa metabolit sekunder (Sudarmo, 2009).

Serai wangi (Andropogon nardus L) dapat bekerja sebagai fungisida, bakterisida dan insektisida. Serai wangi mengandung bahan aktif atsiri yang terdiri dari senyawa sintral, sitronela, geraniol, mirsena, nerol, farnesol, metil heptenon dan di-pentena (Kardinan, 2002). Beberapa hasil penelitian menunjukkan bahwa fungisida nabati yang bersifat anti-fungi cukup efektif dalam mengendalikan berbagai patogen terbawa benih baik secara in vitro maupun in vivo (Tjahjani et al., 2003).

Berdasarkan uraian diatas, maka perlu dilakukan penelitian lebih lanjut mengenai efektifitas fungisida nabati dalam menghambat pertumbuhan koloni patogen terbawa benih. Selain itu penggunaan fungisida nabati ini diharapkan dapat mempengaruhi viabilitas dan vigor benih terung. 


\section{METODE PENELITIAN}

\section{Tempat dan Waktu Penelitian}

Penelitian ini dilaksanakan di Laboratorium Ilmu dan Teknologi Benih Fakultas Pertanian, Universitas Syiah Kuala, Banda Aceh yang dimulai pada bulan Juni hingga Agustus 2017.

\section{Alat dan Bahan Penelitian}

Alat-alat yang digunakan dalam penelitian ini yaitu autoclave, laminar air flow cabinet, germinator, cork borer, erlenmeyer, beaker glass, hand sprayer, oven listrik, pisau, saringan, kompor gas, timbangan analitik, ruang inkubasi, cawan petri, lampu bunsen, gelas ukur, pinset, jarum ose. Sedangkan Bahan-bahan yang digunakan dalam penelitian ini adalah benih terung varietas F1 Mustang, isolat patogen Rhizoctonia solani dan Sclerotium rolfsii, fungisida nabati (minyak serai wangi), media PDA (Potato Dextrose Agar) sebanyak 36 cawan petri, plastic wrap, aluminium foil, Tween 80, alkohol 96\%, alkohol 95\%, kertas merang, kapas steril, aquades, spiritus, bubuk arang sekam, kertas buram.

\section{Rancangan Penelitian}

\section{Percobaan I}

Penelitian ini dilakukan dengan menggunakan Rancangan Acak Lengkap (RAL) pola faktorial. Pada Percobaan I terdiri atas dua faktor, faktor pertama yang diteliti yaitu faktor konsentrasi minyak serai wangi $(\mathrm{K})$, terdiri atas 6 taraf yaitu: $\mathrm{K}_{0}=0,00$ (kontrol); $\mathrm{K}_{1}=0,02$; $\mathrm{K}_{2}=0,04 ; \mathrm{K}_{3}=0,06 ; \mathrm{K}_{4}=0,08 ; \mathrm{K}_{5}=0,10 \%$. Faktor kedua adalah jenis isolat patogen yang terdiri atas 2 taraf yaitu: $\mathrm{P}_{1=}$ Rhizoctonia solani dan $\mathrm{P}_{2}=$ Sclerotium rolfsii. Dengan demikian terdapat 12 kombinasi perlakuan dengan 3 kali ulangan, sehingga perlakuan berjumlah 36 satuan percobaan. Susunan perlakuan dapat dilihat pada Tabel 1.

Tabel 1. Susunan kombinasi perlakuan konsentrasi minyak serai wangi dan jenis patogen terhadap daya hambat pertumbuhan koloni patogen terbawa benih secara in vitro.

\begin{tabular}{ccc}
\hline $\begin{array}{r}\text { Konsentrasi Minyak Serai } \\
\text { wangi }(\%, \mathbf{v} / \mathbf{v})\end{array}$ & Jenis Patogen & $\begin{array}{c}\text { Kombinasi } \\
\text { Perlakuan }\end{array}$ \\
\hline $\mathbf{0 , 0 0}\left(\mathbf{K}_{\mathbf{0}}\right)$ & Rhizoctonia solani $\left(\mathrm{P}_{1}\right)$ & $\mathrm{K}_{0} \mathrm{P}_{1}$ \\
$\mathbf{0 , 0 2}\left(\mathbf{K}_{\mathbf{1}}\right)$ & Rhizoctonia solani $\left(\mathrm{P}_{1}\right)$ & $\mathrm{K}_{1} \mathrm{P}_{1}$ \\
$\mathbf{0 , 0 4}\left(\mathbf{K}_{\mathbf{2}}\right)$ & Rhizoctonia solani $\left(\mathrm{P}_{1}\right)$ & $\mathrm{K}_{2} \mathrm{P}_{1}$ \\
$\mathbf{0 , 0 6}\left(\mathbf{K}_{\mathbf{3}}\right)$ & Rhizoctonia solani $\left(\mathrm{P}_{1}\right)$ & $\mathrm{K}_{3} \mathrm{P}_{1}$ \\
$\mathbf{0 . 0 8}\left(\mathbf{K}_{\mathbf{4}}\right)$ & Rhizoctonia solani $\left(\mathrm{P}_{1}\right)$ & $\mathrm{K}_{4} \mathrm{P}_{1}$ \\
$\mathbf{0 , 1 0}\left(\mathbf{K}_{\mathbf{5}}\right)$ & Rhizoctonia solani $\left(\mathrm{P}_{1}\right)$ & $\mathrm{K}_{5} \mathrm{P}_{1}$ \\
$\mathbf{0 , 0 0}\left(\mathbf{K}_{\mathbf{0}}\right)$ & Sclerotium rolfsii $\left(\mathrm{P}_{2}\right)$ & $\mathrm{K}_{0} \mathrm{P}_{2}$ \\
$\mathbf{0 , 0 2}\left(\mathbf{K}_{\mathbf{1}}\right)$ & Sclerotium rolfsii $\left(\mathrm{P}_{2}\right)$ & $\mathrm{K}_{1} \mathrm{P}_{2}$ \\
$\mathbf{0 , 0 4}\left(\mathbf{K}_{\mathbf{2}}\right)$ & Sclerotium rolfsii $\left(\mathrm{P}_{2}\right)$ & $\mathrm{K}_{2} \mathrm{P}_{2}$ \\
$\mathbf{0 , 0 6}\left(\mathbf{K}_{\mathbf{3}}\right)$ & Sclerotium rolfsii $\left(\mathrm{P}_{2}\right)$ & $\mathrm{K}_{3} \mathrm{P}_{2}$ \\
$\mathbf{0 . 0 8}\left(\mathbf{K}_{\mathbf{4}}\right)$ & Sclerotium rolfsii $\left(\mathrm{P}_{2}\right)$ & $\mathrm{K}_{4} \mathrm{P}_{2}$ \\
$\mathbf{0 , 1 0}\left(\mathbf{K}_{\mathbf{5}}\right)$ & Sclerotium rolfsii $\left(\mathrm{P}_{2}\right)$ & $\mathrm{K}_{5} \mathrm{P}_{2}$ \\
\hline
\end{tabular}

Keterangan: K= Konsentrasi Fungisida Nabati; $\mathrm{P}=$ Jenis Patogen 


\section{Percobaan II}

Penelitian ini menggunakan Rancangan Acak Lengkap (RAL) pola non faktorial. Faktor yang di teliti adalah fungisida nabati jenis minyak serai wangi dengan 4 taraf yang diuji yaitu: $\mathrm{K}_{0}=0,00$ (kontrol); $\mathrm{K}_{1}=0,01 ; \mathrm{K}_{2}=0,02 ; \mathrm{K}_{3}=0,03$. Masing-masing taraf percobaan dilakukan sebanyak 5 kali ulangan.

\section{Prosedur Penelitian}

\section{Percobaan I}

\section{Pembuatan Media PDA (Potato Dextrose Agar)}

Kentang sebanyak $200 \mathrm{~g}$ dicuci bersih dan dikupas kulitnya. Setelah bersih, kentang dipotong dadu kecil kemudian direbus dengan aquadest $500 \mathrm{ml}$ sampai mendidih, lalu disaring ekstraknya. Kemudian didihkan aquadest $500 \mathrm{ml}$ bersama dengan agar sebanyak $15 \mathrm{~g}$ dan dextrose sebanyak $20 \mathrm{~g}$, diaduk hingga keduanya larut. Jika sudah larut dengan baik, larutan agar dan ekstrak kentang yang telah disaring disatukan didalam beaker glass berukuran 1 liter. Kemudian dimasukkan dalam erlenmeyer, ditutup dengan kapas steril dan dilapisi dengan aluminium foil. Larutan PDA disterilisasi menggunakan autoclave selama 15 menit pada suhu $121^{\circ} \mathrm{C}$. Setelah disterilisasi, larutan PDA dibiarkan hingga suhunya menjadi lebih hangat dari sebelumnya dan tuang ke dalam cawan petri sebanyak $10 \mathrm{ml}$. Larutan PDA tersebut kemudian disimpan di Laminar Air Flow Cabinet hingga agarnya menjadi padat dan siap digunakan (Gandjar et al., 1999).

\section{Persiapan Isolat Patogen Terbawa Benih}

Isolat patogen terung yang digunakan dalam penelitian ini adalah $R$. solani dan S.rolfsii yang diperoleh dari Laboratorium Ilmu dan Teknologi Benih Program Studi Agroteknologi Fakultas Pertanian Universitas Syiah Kuala Darussalam Banda Aceh. Isolat tersebut merupakan koleksi dari Laboratorium Ilmu dan Teknologi Benih yang diisolasi dari bagian tanaman cabai yang terserang penyakit. Sebelumnya dilakukan peremajaan isolat patogen terlebih dahulu pada media PDA, kemudian diinkubasi pada suhu ruang yaitu $25{ }^{\circ} \mathrm{C}$ selama 5-7 hari.

\section{Persiapan Bahan Fungisida Nabati}

Fungisida nabati yang digunakan pada penelitian ini adalah ekstrak serai wangi. minyak serai wangi yang digunakan merupakan salah satu fungisida nabati koleksi Laboratorium Ilmu dan Teknologi Benih Program Studi Agroteknologi Fakultas Pertanian Universitas Syiah Kuala Darussalam Banda Aceh. Ekstraksi serai wangi ini dilakukan dengan cara penyulingan. Proses ekstraksi minyak nabati dilakukan di Laboratorium Pengolahan Hasil, Balai Penelitian Tanaman Rempah dan Obat (BALITTRO) Departemen Pertanian, Cimanggu Bogor.

\section{Percobaan II \\ Persiapan Benih}

Benih yang digunakan adalah benih terung varietas F1 Mustang diperoleh dari toko Sarana Tani di Lambaro, Aceh Besar. Jumlah benih yang dibutuhkan pada penelitian ini sebanyak 500 butir. 


\section{Aplikasi Fungisida Nabati Melalui Perlakuan Benih}

Perlakuan benih menggunakan konsentrasi fungisida nabati dilakukan dengan cara yaitu benih terung dimasukkan ke dalam botol kultur, lalu ditambahkan larutan fungisida nabati sesuai konsentrasi yang terbaik pada uji in vitro. Didalam larutan ditambahkan bubuk arang sekam sesuai konsentrasi yang dicobakan pada benih. Benih dan larutan diaduk 5 menit sampai permukaan benih basah. Botol kultur ditutup menggunakan plastik transparan dan diikat dengan karet. Larutan minyak fungisida nabati dibuat dengan melarutkan minyak tersebut ke dalam aquades sesuai konsentrasi masing-masing, dan sebagai pelarut dimasukkan Tween 80 yang jumlahnya sama seperti konsentrasi minyak serai wangi. Setiap konsentrasi diaduk rata kemudian ditambahkan aquades $(100 \mathrm{ml})$ diaduk rata lagi. Percobaan ini dilakukan pada ruang bercahaya dengan suhu $20-21^{\circ} \mathrm{C}$ dan didiamkan selama 2-3 jam. Setelah direndam 2-3 jam, benih dikeluarkan dan diayak untuk menghilangkan bahan yang melekat pada benih. Kemudian benih dikering anginkan selama 30 menit.

\section{Perkecambahan Benih}

Benih yang telah mendapat perlakuan konsentrasi fungisida nabati selanjutnya dikecambahkan dalam cawan petri menggunakan kertas buram sebagai media perkecambahan. Setiap perlakuan ditanam 25 benih per cawan petri dan dilakukan ulangan sebanyak lima kali.

\section{Peubah yang diamati}

\section{Percobaan I}

Daya Hambat Konsentrasi Fungisida Nabati terhadap Pertumbuhan Koloni Patogen Terbawa Benih secara In Vitro.

Daya hambat fungisida nabati terhadap pertumbuhan cendawan patogen dapat dihitung dengan menggunakan rumus Soytong (1988) dalam Noveriza (2003) yang dimodifikasi sebagai berikut:

$$
\text { Daya Hambat }(\mathrm{DH})(\%)=\mathrm{d}_{1}-\mathrm{d}_{2} / \mathrm{d}_{1} \times 100
$$

Keterangan:

$\mathrm{d}_{1}=$ diameter koloni kontrol $(\mathrm{cm})$

$\mathrm{d}_{2}=$ diameter koloni perlakuan $(\mathrm{cm})$

Penilaian daya hambat terhadap $R$. solani dan S.rolfsii ditentukan berdasarkan skala persentase penghambatan pertumbuhan koloni sebagai berikut: aktifitas sangat tinggi $(++++=$ $>75 \% \mathrm{DH})$, aktivitas tinggi $(+++=61-75 \% \mathrm{DH})$, aktivitas sedang $(++=51-60 \% \mathrm{DH})$, aktivitas rendah $(+=<50 \% \mathrm{DH})$ dan tidak ada aktifitas (-).

\section{Percobaan II}

\section{Potensi Tumbuh Maksimum (PTM)}

Potensi Tumbuh maksimum (PTM) merupakan viabilitas total adalah total benih hidup atau yang menujukkan gejala hidup (Sadjad et al., 1999). PTM diamati dengan cara 
menghitung jumlah benih yang berkecambah pada hari terakhir pengamatan (14 HST). PTM merupakan persentase munculnya kecambah yang dihitung berdasarkan jumlah benih yang tumbuh terhadap benih yang ditanam.

$$
\operatorname{PTM}(\%)=\frac{\Sigma \text { Benih yang menunjukkan gejala tumbuh }}{\Sigma \text { Benihyang ditanam }} \times 100 \%
$$

\section{Daya Berkecambah (DB)}

Daya berkecambah menggambarkan viabilitas potensial benih (Sadjad et al., 1999), yang dihitung berdasarkan jumlah benih yang berkecambah normal $(\mathrm{KN})$ pada umur 7 HST dan 14 HST yang dihitung berdasarkan rumus:

$$
\text { DB }(\%)=\frac{\Sigma \text { KN hitungan I }+\Sigma \text { KN hitungan II }}{\Sigma \text { Benih yang ditanam }} \times 100 \%
$$

\section{Keserempakan Tumbuh $\left(\mathbf{K}_{\mathrm{ST}}\right)$}

Keserempakan tumbuh diamati dengan menghitung jumlah kecambah normal pada hari ke-10 yang dinyatakan dalam persen dengan rumus:

$$
\mathrm{K}_{\mathrm{ST}}(\%)=\frac{\Sigma \text { Benih yang berkecambah normal }}{\mathrm{\Sigma} \text { Benihyang ditanam }} \times 100 \%
$$

\section{Indeks Vigor (IV)}

Indeks vigor menggambarkan vigor kecepatan tumbuh yang dinyatakan dalam satuan persen (Copeland dan McDonald, 1995). Indeks Vigor (IV) dihitung berdasarkan persentase kecambah normal pada hitungan pertama dengan rumus:

$$
\text { IV }(\%)=\frac{\Sigma \text { KN hitungan } 1}{\Sigma \text { Benihyang ditanam }} \times 100 \%
$$

\section{Kecepatan Tumbuh Relatif $\left(\mathrm{K}_{\mathrm{CT}}-\mathbf{R}\right)$}

Kecepatan tumbuh menggambarkan vigor benih, dihitung berdasarkan perbandingan nilai $\mathrm{K}_{\mathrm{CT}}$ dengan $\mathrm{K}_{\mathrm{CT}}$ maksimum. $\mathrm{K}_{\mathrm{CT}}$ maksimum diperoleh dari asumsi bahwa kecambah normal sudah mencapai $100 \%$ pada saat hitungan pertama. Pengamatan dilakukan setiap hari selama waktu perkecambahan yaitu 14 hari. Rumus perhitungannya adalah:

$$
\mathrm{K}_{\mathrm{CT}}=\sum_{o}^{t n} \frac{N}{t}
$$

Keterangan :

$\mathrm{t}$ = waktu pengamatan

$\mathrm{N}=\% \mathrm{KN}$ setiap waktu pengamatan

tn $=$ waktu akhir pengamatan

Perhitungan $\mathrm{K}_{\mathrm{CT}}-\mathrm{R}$ untuk benih:

$$
\mathrm{K}_{\mathrm{CT}} \text { maks }=\frac{100}{\Sigma \text { hari hitungan I }}=\frac{100}{7}=14,286 \% / \mathrm{etmal}
$$


$\mathrm{K}_{\mathrm{CT}}$ relative $=\frac{\mathrm{KCT}}{14,286} \times 100 \%$

$\mathbf{T}_{50}$ (hari)

$\mathrm{T}_{50}$ merupakan waktu yang dibutuhkan untuk mencapai $50 \%$ perkecambahan total, dihitung berdasarkan jumlah benih yang berkecambah setiap harinya hingga mencapai $50 \%$ (Khan, 1992). Pengamatannya dilakukan setiap hari. Rumus yang digunakan adalah:

$$
\mathrm{T}_{50}(\text { hari })=\mathrm{ti}+\left(\frac{(\mathrm{n} 50-\mathrm{ni}}{\mathrm{nj}-\mathrm{ni}}\right)(\mathrm{tj}-\mathrm{ti})
$$

Keterangan:

Ti = waktu (hari) batas bawah sebelum mencapai $50 \%$ perkecambahan

$\mathrm{tj} \quad=$ waktu antara setelah benih berkecambah $50 \%$

$\mathrm{n} 50 \%=$ jumlah benih berkecambah (50\% dari total yang berkecambah)

$\mathrm{nj} \quad=$ jumlah kecambah batas atas setelah mencapai $50 \%$ total perkecambahan

ni = jumlah kecambah batas bawah sebelum mencapai $50 \%$ total perkecambahan

\section{Berat Kering Kecambah Normal (BKKN)}

Penentuan berat kering kecambah normal ditentukan dengan cara semua kecambah normal dikeringkan terlebih dahulu menggunakan oven pada suhu $60^{\circ} \mathrm{C}$ selama $3 \mathrm{X} 24$ jam. Berat kering kecambah normal ditentukan dengan menimbang semua kecambah normal yang sudah dikeringkan dan ditentukan berat kering rata-rata per kecambah normal. Berat kering kecambah normal dinyatakan dalam gram.

\section{HASIL DAN PEMBAHASAN}

\section{Efektifitas Daya Hambat Minyak Serai Wangi terhadap Pertumbuhan Koloni Patogen Secara In Vitro}

Hasil uji daya hambat minyak serai wangi dilakukan terhadap masing-masing patogen (R.solani dan S. rolfsii) secara in vitro disajikan pada Tabel 3. Berdasarkan hasil persentase pengamatan daya hambat minyak serai wangi dengan berbagai konsentrasi minyak serai wangi berpengaruh sangat nyata terhadap pertumbuhan koloni patogen terbawa benih secara in vitro.

Tabel 2. Persentase Daya Hambat Minyak Serai Wangi terhadap Pertumbuhan Patogen R.solani dan S. rolfsii Pada Medium Potato Dextrose Agar (PDA)

\begin{tabular}{|c|c|c|c|c|c|c|}
\hline \multirow{2}{*}{$\begin{array}{c}\text { Jenis } \\
\text { Patogen }\end{array}$} & \multicolumn{6}{|c|}{ Konsentrasi Minyak Serai wangi $(\%, \mathrm{v} / \mathrm{v})$} \\
\hline & $\mathbf{0 , 0 0}$ & $\mathbf{0 , 0 2}$ & $\mathbf{0 , 0 4}$ & 0,06 & $\mathbf{0 , 0 8}$ & $\mathbf{0 , 1 0}$ \\
\hline \multirow{2}{*}{ R. solani } & 0.00 & 75.92 & 82.22 & 92.99 & 100.00 & 100.00 \\
\hline & (2.87) $\mathrm{Aa}$ & (60.69) $\mathrm{Ab}$ & (65.22) Abc & (77.75) Bcd & (90.00) Ad & (90.00) Ad \\
\hline S. rolfsii & $\begin{array}{c}0.00 \\
(2.87) \mathrm{Aa}\end{array}$ & $\begin{array}{c}62.96 \\
(52.52) \mathrm{Ab}\end{array}$ & $\begin{array}{c}62.96 \\
(5252) \mathrm{Ab}\end{array}$ & $\begin{array}{c}79.63 \\
(6275)\end{array}$ & $\begin{array}{c}92.96 \\
\end{array}$ & 100.00 \\
\hline & & & (JL.JL) R & (02.17) & $(1,1.12)(2)$ & $(70.00)$ ( \\
\hline
\end{tabular}

Keterangan: Angka yang sama diikuti oleh huruf yang sama, tidak berbeda nyata berdasarkan uji Beda Nyata Jujur (BNJ) pada taraf nyata $\alpha=0,05$ (huruf besar dibaca vertikal, huruf kecil dibaca horizontal). Data ditransformasi dengan Arc $\sin \sqrt{ } \mathrm{x}$

Hasil uji daya hambat minyak serai wangi terhadap patogen menunjukkan bahwa masing-masing perlakuan konsentrasi memberikan respon yang berbeda terhadap kedua 
patogen uji. Hasil evaluasi daya hambat minyak serai wangi memberikan daya hambat yang sangat efektif terhadap patogen R.solani meskipun pada konsentrasi yang sangat rendah yaitu $0,02 \%$ untuk mendapatkan aktivitas daya hambat sangat tinggi yang mencapai $(75,92 \%)$. Daya penghambatan $100 \%$ diperoleh dengan pemberian minyak serai wangi pada konsentrasi $0,08 \%$.

Hal yang berbeda ditunjukkan terhadap patogen S.rolfsii dimana konsentrasi minyak serai wangi yang efektif memberikan daya hambat yang tinggi pada konsentrasi 0,06 yaitu mencapai 79,63\%. Sementara konsentrasi $0,10 \%$, mampu memberikan efek penghambatan terhadap pertumbuhan koloni patogen $S$. rolfsii secara sempurna (100\%).

Daun serai wangi mempunyai daya antifungi yang didalamnya terdapat zat-zat yang terkandung senyawa sitronelal dan geraniol, serta senyawa triterpenoid. Menurut Sastrohamidjojo (2004), kemampuan komponen terpenoid yang terdapat pada pestisida nabati dalam menghambat proses metabolisme, yaitu dengan cara mengakumulasi globula lemak di dalam sitoplasma sel, mengurangi jumlah organel-organel sel terutama mitokondria dan merusak membran nukleus sel cendawan. Senyawa terpenoid ini dapat juga mempengaruhi pengambilan nutrien oleh sel dari lingkungannya (Larber dan Muller, 1976), sehingga akibatnya dapat menghambat kebutuhan energi (ATP) dan selanjutnya pertumbuhan dan perkembangan hifa menjadi berkurang dan hifa menjadi pendek-pendek. Akibatnya miselium yang terbentuk menjadi berkurang dan pertumbuhan koloni menjadi tidak normal.

Senyawa-senyawa yang terkandung didalam minyak serai wangi harus masuk ke dalam sel agar dapat menghambat pertumbuhan cendawan. Senyawa-senyawa tersebut masuk ke dalam sel melalui dinding sel. Menurut Leite et al. (2014) senyawa terpenoid khususnya geraniol bekerja mematikan atau menghambat petumbuhan cendawan dengan cara merusak integritas membrane sel tetapi bukan dengan mengganggu metabolisme sorbitol dan ergosterol, tetapi dengan meningkatkan pengeluaran potassium ke luar sel. Menurut Istianto dan Eliza (2009) minyak daun serai wangi dapat menekan perkembangan miselium Colletotrichum sp sebesar 60-62\%.

Menurut Syamsuddin et al. (2007) konsentrasi minyak serai wangi 0,015\%, telah menyebabkan pertumbuhan koloni patogen $R$. solani dan $S$. rolfsii terhambat sempurna $(100 \%)$. Hal ini menunujukkan bahwa minyak serai wangi mengandung minyak atsiri yang memiliki potensi sebagai fungisida nabati yang berguna untuk menghambat pertumbuhan cendawan.

\section{Pengaruh Perlakuan Benih Menggunakan Minyak Serai Wangi terhadap Viabilitas dan Vigor Benih Terung}

Hasil analisis ragam (uji F) pada lampiran 8,10,12,14,16,18 menunjukkan bahwa konsentrasi minyak serai wangi berpengaruh sangat nyata terhadap Potensi Tumbuh Maksimum (PTM), Daya Berkecambah (DB), Keserempakan Tumbuh $\left(\mathrm{K}_{\mathrm{ST}}\right)$, Kecepatan Tumbuh Relatif ( $\left.\mathrm{K}_{\mathrm{CT}}-\mathrm{R}\right)$, Waktu Mencapai $50 \%$ perkecambahan total relatif $\left(\mathrm{T}_{50}\right)$ dan Indeks Vigor (IV). Sementara hasil uji F pada lampiran 4 menunjukkan bahwa konsentrasi minyak serai wangi tidak berpengaruh nyata Berat Kering Kecambah Normal (BKKN).

Rata-rata viabilitas dan vigor benih terung yang mendapat perlakuan konsentrasi minyak serai wangi yang diamati berdasarkan potensi tumbuh maksimum (PTM), daya berkecambah (DB), indeks vigor (IV), keserempakan tumbuh $\left(\mathrm{K}_{\mathrm{ST}}\right)$, kecepatan tumbuh relatif 
$\left(\mathrm{K}_{\mathrm{CT}}-\mathrm{R}\right)$, Waktu mencapai $50 \%$ perkecambahan total relatif $\left(\mathrm{T}_{50}\right)$ dan Berat Kering Kecambah Normal (BKKN) dapat dilihat pada Tabel 5.

Tabel 5. Rata-rata Tolok Ukur Viabilitas dan Vigor Benih pada Beberapa Konsentrasi Minyak Serai Wangi.

\begin{tabular}{cccccccc}
\hline \multirow{2}{*}{$\begin{array}{c}\text { Konsentrasi } \\
(\%)\end{array}$} & $\begin{array}{c}\text { PTM } \\
(\%)\end{array}$ & $\begin{array}{c}\mathrm{DB} \\
(\%)\end{array}$ & $\begin{array}{c}\mathrm{IV} \\
(\%)\end{array}$ & $\begin{array}{c}\mathrm{K}_{\mathrm{ST}} \\
(\%)\end{array}$ & $\begin{array}{c}\mathrm{K}_{\mathrm{CT}-\mathrm{R}} \\
(\%)\end{array}$ & $\begin{array}{c}\mathrm{T}_{50} \\
(\mathrm{H})\end{array}$ & $\begin{array}{c}\mathrm{BKK}) \\
(\mathrm{mg})\end{array}$ \\
\hline $\mathbf{0 , 0 0}$ & $89,60 \mathrm{c}$ & $80,00 \mathrm{c}$ & $20,80 \mathrm{c}$ & $49,60 \mathrm{~b}$ & $63,91 \mathrm{~b}$ & $4,12 \mathrm{a}$ & 0.06 \\
$\mathbf{0 , 0 1}$ & $76,00 \mathrm{~b}$ & $67,20 \mathrm{~b}$ & $19,20 \mathrm{bc}$ & $44,00 \mathrm{~b}$ & $57,25 \mathrm{~b}$ & $4,82 \mathrm{ab}$ & 0.05 \\
$\mathbf{0 , 0 2}$ & $49,60 \mathrm{a}$ & $40,80 \mathrm{a}$ & $16,00 \mathrm{~b}$ & $28,00 \mathrm{a}$ & $35,67 \mathrm{a}$ & $5,40 \mathrm{~b}$ & 0.04 \\
$\mathbf{0 , 0 3}$ & $39,20 \mathrm{a}$ & $34,40 \mathrm{a}$ & $7,20 \mathrm{a}$ & $23,20 \mathrm{a}$ & $28,84 \mathrm{a}$ & $4,44 \mathrm{a}$ & 0.04 \\
\hline BNJ 0,05 & 11,04 & 11,56 & 5,84 & 10,25 & 8,61 & 0,77 & - \\
\hline
\end{tabular}

Keterangan: Angka yang diikuti oleh huruf yang sama pada kolom yang sama tidak berbeda nyata berdasarkan uji Beda Nyata Jujur (BNJ) pada $\alpha=0,05$. PTM: potensi tumbuh maksimum; DB: daya berkecambah; dan IV: indeks vigor; $\mathrm{K}_{\mathrm{ST}}$ : keserempakan tumbuh; $\mathrm{K}_{\mathrm{CT}}-\mathrm{R}$ : kecepatan tumbuh relatif; dan T50: waktu yang dibutuhkan untuk mencapai $50 \%$ perkecambahan total relatif; BKKN: Berat Kering Kecambah Normal.

Tabel 6 menunjukkan bahwa perbedaan konsentrasi minyak serai wangi diikuti oleh perbedaan nilai viabilitas dan vigor benih terung yang diamati. Semakin tinggi konsentrasi yang diberikan menyebabkan terjadinya penurunan nilai PTM, DB, IV, $\mathrm{K}_{\mathrm{ST}}, \mathrm{K}_{\mathrm{CT}}-\mathrm{R}$, dan BKKN. Namun terhadap waktu yang dibutuhkan untuk mencapai $50 \%$ perkecambahan total relatif $(50 \%)$, ternyata hasilnya tidak berbeda nyata antara benih yang diberi perlakuan konsentrasi minyak serai wangi hingga $0,03 \%$ tidak berbeda dengan benih tanpa perlakuanBerdasarkan hasil pengamatan (Tabel 5), terdapat tiga konsentrasi yang menjadi tolok ukur viabilitas benih. Hasil uji minyak serai wangi terhadap tiga konsentrasi menunjukkan bahwa minyak serai wangi pada konsentrasi $0,01 \%$ memiliki viabilitas dan vigor benih yang lebih tinggi dibandingkan benih yang mendapatkan perlakuan minyak serai wangi pada konsentrasi $0,02 \%$ dan $0,03 \%$.

Penurunan nilai $\mathrm{PTM}, \mathrm{DB}, \mathrm{IV}, \mathrm{K}_{\mathrm{ST}}, \mathrm{K}_{\mathrm{CT}}-\mathrm{R}$, dan $\mathrm{BKKN}$ terjadi penurunan secara signifikan mulai dari pemberian konsentrasi minyak serai wangi $0,02 \%$. Hasil penelitian dapat disimpulkan bahwa pemberian konsentrasi $0,02 \%$ ke atas memberi pengaruh negatif terhadap perkecambahan benih.

Perlakuan matriconditioning dengan fungisida nabati mampu meningkatkan viabilitas dan vigor benih yang lebih baik dibandingkan dengan perlakuan hidrasi lain, hal ini terbukti berhasil memperbaiki vigor dan viabilitas kacang-kacangan dan sayur-sayuran. Selain itu, perlakuan matriconditioning juga mampu meningkatkan daya perkecambahan benih, meningkatkan kemampuan tumbuh dan produksi di lapangan (Khan et al., 1990). Seperti halnya dengan perlakuan benih menggunakan fungisida nabati jenis minyak serai wangi dapat meningkatkan perkecambahan benih. Bahan aktif yang terkandung dalam minyak serai wangi seperti senyawa mirsena, sitral, farnesol, sitronella, nerol, metil heptena, dan di-pentena diduga mempengaruhi daya berkecambah benih terung.

Hasil penelitian Astuti (2009) menunjukkan bahwa perlakuan matriconditioning efektif meningkatkan viabilitas dan vigor benih terhadap indeks vigor, daya berkecambah dan kecepatan tumbuh relatif, khususnya perlakuan benih menggunakan serai wangi. Perlakuan 
matriconditiong menggunakan fungisida nabati mampu meningkatkan viabilitas dan vigor benih, disebabkan oleh imbibisi air kedalam benih akan terkontrol oleh faktor media.

Hasil penelitian Asie (2004) perlakuan matriconditioning menggunakan tepung dan minyak cengkeh atau serai wangi pada benih cabai mampu meningkatkan mutu benih secara signifikan dibanding kontrol pada tolok ukur PTM, DB, BKKN, IV, $\mathrm{K}_{\mathrm{CT}}$ relatif serta dapat menurunkan T50. Sebaliknya, Karangan (2004) melaporkan bahwa perlakuan matriconditioning menggunakan minyak serai wangi $0,02 \%$ memberikan pengaruh peningkatan waku dalam pencapaian $50 \%$ pemunculan kecambah, penurunan berat kering kecambah normal, kecepatan tumbuh relatif dan indeks vigor pada benih cabai merah.

Secara umum, hasil pengujian viabilitas dan vigor benih terhadap tolok ukur potensi tumbuh maksimum, daya berkecambah, keserempakan tumbuh, indeks vigor, kecepatan tumbuh relative, T50 dan BKKN menunjukkan bahwa perlakuan benih dengan minyak serai wangi tidak memberikan pengaruh negatif terhadap viabilitas dan vigor benih apabila konsentrasi yang digunakan cukup tepat. Hal ini disebabkan karena minyak serai wangi bersifat sebagai protektan dan fungisidal terhadap patogen, juga aman terhadap benih (tidak merusak benih). Namun, pemberian konsentrasi minyak serai wangi perlu dipertimbangkan, karena konsentrasi minyak serai wangi yang terlalu tinggi dapat meracuni benih sehingga mempengaruhi viabilitas dan vigor benih.

\section{KESIMPULAN}

Minyak serai wangi memiliki potensi untuk menghambat pertumbuhan patogen Rhyzoctonia solani dan Sclerotium rolfsii. Konsentrasi minimum minyak serai wangi yang dapat menghambat pertumbuhan patogen R.solani secara sempurna (100\%) adalah $0,08 \%$, sedangkan untuk patogen S.rolfsii adalah $0,10 \%$. Konsentrasi minyak serai wangi pada perlakuan benih paling efektif pada konsentrasi $0,01 \%$, karena apabila pemberian konsentrasi terlalu tinggi dikhawatirkan akan menimbulkan kerusakan dan mengganggu daya berkecambah benih.

\section{DAFTAR PUSTAKA}

Asie, K.V. 2004. Matriconditioning plus pestisida botani untuk perlakuan benih cabai terinfeksi Colletotricum capsici: evaluasi mutu benih selama penyimpanan. Tesis. Institut Pertanian Bogor, Bogor.

Astuti, D. 2009. Pengaruh matriconditioning plus minyak cengkeh terhadap viabilitas, vigor dan kesehatan benih padi (Oryza sativa) yang terinfeksi Altenaria padwickii (Ganguly) M.B. Ellis. Skripsi. Institut Pertanian Bogor, Bogor.

BPS, Direktorat Jenderal Hortikultura, Departemen Pertanian. 2016. Produktivitas Sayuran di Indonesia, 2011-2015. http://www.pertanian.go.id/Data5tahun/PdfHORTI2016/3 Produktivitas\%20\%20Nasional\%20sayuran.pdf. [22 Maret 2017].

Brandl, F. 2001. Seed treatment technologies, envolving the achieve crop genetic potential. Dalam A.J. Biddle (Eds.) Seed Treatment Challengers and Opportunities. Symposium Proceedings No. 76, North Warwickshire. 
Gandjar, I., R.A. Samson., K.Van Den Tweel-Vermeulen., A. Oetari dan I. Santosa. 1999. Pengenalan Kapang Tropik. Universitas Indonesia, Jakarta.

Kardinan, A. 2002. Pestisida Nabati Ramuan dan Aplikasi. Penebar Swadaya, Jakarta.

Khan, A.A., H. Miura, J. Prusinski, dan S. Ilyas. 1990. Matriconditioning of seed to improve emergence. Proceeding of the Symposium on Stand Establishment of Horticultural Crops. Minnesota. p 19-40.

Lorber, P dan W.H Muller. 1976. Volatile growth inhibitors produced by Salvia leucophylla: effects on seedling root tip ultrastructure. Amer. J. Bot. 63: 196-200.

Leite, M.C.A., A.P.B. Bezerra, J.P Sousa dan E.O. Lima. 2014. Investigating the antifungal activity and mechanism (s) of geraniol against Candida albicans strains. Medical Mycology. 1-10.

Mamik. 2016. Penyakit pada tanaman terung. http://bp4k.blitarkab.go.id/wpcontent/uploads/2016pdf. [20 April 2017].

Maude, R.B. 1996. Seedborne disease and their control, principles and practice. CAB International. Wallingford, UK.

Naqvi, S.D.Y., T. Shiden, W. Merhawi dan S.Mehret. 2013. Identification of seed borne fungi on farmer saved sorghum (Sorghum bicolor L.), pearl millet (Pennisetum glaucum L.) and groundnut (Arachis hypogaea L.) seeds. Agricultural Science Research Journal. 3(4): 107-114.

Noveriza, R. 2003. Soil mycloflora in the rhyzosphere of black pepper (Piper negrum L.) and their antagonisms against Phytophthora capsici. Thesis. Department of Plant Pathology, University of The Philipines at Los Banos, College, Laguna, Philippines.

Sadjad, S., E. Muniarti dan S. Ilyas. 1999. Parameter Pengujian Vigor Benih dari Komperatif ke Simulatif. Grasindo, Jakarta.

Sastrohamidjojo, A. 2004. Kimia Minyak Atsiri. UGM Press, Yogyakarta.

Simatupang, A. 2010. Pengaruh beberapa jenis pupuk organik terhadap pertumbuhan dan hasil tanaman terung (Solanum melongena L.). Skripsi. Fakultas Pertanian Universitas Andalas, Padang.

Sudarmo, S. 2009. Pestisida Nabati: Pembuatan dan Pemanfaatannya. Kanisius, Yogyakarta.

Syamsuddin., S. Ilyas., D. Manohara dan Sudarsono. 2007. Efektifitas daya hambat minyak nabati terhadap pertumbuhan koloni patogen terbawa benih cabai secara in vitro. J. Agrista, 11(2): 81-91.

Tjahjani, A., S. Rahayu dan Supartini. 2003. Pengaruh ekstraksi daun mimba dan daun sirih terhadap penyakit antraknosa pada buah cabai merah (Capsicum annum). Prosiding Forum Komunikasi Ilmiah. Pemanfaatan Pestisida Nabati (9-10 November 1999). Bogor. 